\title{
CHARACTERISTICS OF PERFORMANCE AND EMISSIONS IN A DIRECT- INJECTION DIESEL ENGINE FUELLED WITH KEROSENE/DIESEL BLENDS
}

\author{
K. R.Patil ${ }^{1, *}$ and S. S.Thipse ${ }^{2}$ \\ ${ }^{1}$ Symbiosis International University, Pune; Faculty of Mechanical Engineering, \\ Marathwada Mitra Mandal's College of Engineering, Karvenagar, \\ Pune,411052, India \\ *Email: krpatil68@gmail.com \\ ${ }^{2}$ The Automotive Research Associationof India (ARAI), Pune, India
}

\begin{abstract}
An experimental investigation has been carried out to evaluate the effect of kerosene as an additive to diesel fuel on the combustion, performance and emission characteristics of a direct-injection diesel engine, typically used in gensets and agricultural pumps over the entire load range. The engine tests were carried out as per the ISO 8178-D2 fivemode test cycle procedure for baseline diesel fuel and three blend fuels at different engine loads. In this study, 5\%,10\% and 15\% kerosene (by volume) were blended into diesel and denoted as K5D, K10D and K15D, respectively. Laboratory fuels tests showed that beyond $15 \%$ kerosene blend, the viscosity and density of the blended fuel reduces compared with the acceptable limits, which can further reduce lubricity and create potential wear problems in sensitive fuel-injection pumps and fuel-injector designs. The experimental test results showed that theK5D blend had low smoke, low $\mathrm{NO}_{\mathrm{x}}$, high brake thermal efficiency and low brake specific fuel consumption compared with K10D and K15D blend. An overview of the results show that the K5D blend is the most favourable blend compared with K10D and K15Don the basis of performance and emission characteristics.
\end{abstract}

Keywords: Kerosene-diesel blend; combustion; performance; emission.

\section{INTRODUCTION}

The limited reserves of crude oil and environmental protection policies have spurred the development of alternative fuels worldwide. Most of the initial interest in alternative fuels started after the oil crisis in the 1970s. With increasing concern about energy shortages and environmental protection, research on reducing exhaust emissions, reducing fuel consumption, reducing engine noise and increasing specific outputs has become the major researching aspect in combustion and engine development $[1,2]$. Alternative fuels, such as compressed natural gas $(\mathrm{CNG})$, blend of hydrogen with CNG (HCNG), liquefied petroleum gas (LPG), liquefied natural gas (LNG), biodiesel, biogas, hydrogen, ethanol, methanol, dimethyl ether [3], diethyl ether (DEE), producer gas, Pseries have been tried worldwide [4-6]. Furthermore, non-edible vegetable oils such as thumba, jojoba, neem oil, and jojoba methyl ester can be used in automotive engines with minor modifications [7-11]. In parallel to this interest in alternative fuels; there has also been increased interest in homogenous charge compression ignition (HCCI) combustion technology, which incorporates the advantages of both spark ignition and 
compression ignition combustion technology [12-14]. Along with automotive vehicles the use of stationary engines is increasing at a rapid rate. The most popular applications are gensets due to the uncertain supply of electricity and agriculture water pumps. These gensets and pumps use gasoline, diesel, kerosene and adulterated fuels. Fuel adulteration by blending kerosene with gasoline or diesel is becoming a widespread problem because of the financial benefits resulting from the price difference between the two fuels [15].

Kerosene is a common adulterant utilised for mixing with diesel. The literature related to the effect of kerosene on diesel fuel properties shows that kerosene improves the cold flow characteristics of diesel fuel by simply diluting the problematic paraffin waxes present in the diesel fuel distillation curve. Baral and Raine [15] and Yadav et al. [16] have reported that the density of the kerosene-diesel blend remains within the prescribed limit even in higher blends, while kinematic viscosity is considerably decreased with an increase in blend ratio. Experimental work related to kerosene-diesel blends is carried out by very few researchers. Yadav et al. [16] have demonstrated experimentally that the percent opacity value decreased sharply even at a small adulteration level of kerosene with diesel. Bergstrand [17] has reported that kerosene has a lower cetane number than diesel, thus giving a longer ignition delay, making it viable for lower emissions. He has also observed lower soot emissions with the blends of kerosene with diesel at low load compared with neat diesel, while soot emission was similar to that of diesel fuel at high load. Pathak et al. [18] have conducted engine tests for a detailed investigation on the effects of kerosene on spark ignition (SI) engine gensets and reported that kerosene-run gensets are more cost-effective than gasoline gensets and produces less noise in comparison to diesel gensets. Although adulteration is a widespread problem, the effects of kerosene adulteration have not been assessed adequately. Some studies have been dedicated to the detection of kerosene adulteration effects on diesel/gasoline fuel properties. However, very few studies have reported kerosene adulteration effects on the performance and emissions of diesel engines. Hence, the present experimental work has been undertaken to evaluate the performance, emissions and combustion characteristics of a diesel engine running on kerosene-diesel blends and to find out the optimum performance kerosene-diesel blend.

\section{MATERIALS AND METHODS}

\section{Kerosene-Diesel Blend Properties}

Commercial diesel fuel and the kerosene were procured from local commercial representatives. The conventional diesel fuel was blended with kerosene in different proportions by manual mixing at room temperature. In this study, 5\%, 10\% and 15\% kerosene (by volume) were blended into diesel and denoted hereafter and in the figures as $\mathrm{K} 5 \mathrm{D}, \mathrm{K} 10 \mathrm{D}$ and $\mathrm{K} 15 \mathrm{D}$, respectively. The neat diesel and neat kerosene were denoted as D100 and K100, respectively. The basic properties such as density, kinematic viscosity, calorific value, flash point and distillation profile were measured in the laboratory according to the ASTM test method. Some important physiochemical properties of the base fuels and kerosene-diesel blends are shown in Table 1. As seen in Table 1, increasing the concentration of kerosene in the blends decreases the density, calorific value, kinematic viscosity and cetane number of the blended fuel compared with neat diesel, but increases these values compared with neat kerosene. Yadav et al. [16] have reported that no appreciable density variation at different levels of 
adulteration was observed, while a considerable decrease in kinematic viscosity was noted at higher adulteration levels of kerosene with diesel.

Table 1. Properties of kerosene-diesel blend fuels.

\begin{tabular}{lllllll}
\hline $\begin{array}{l}\text { Fuel } \\
\text { Blend }\end{array}$ & $\begin{array}{l}\text { Density } \\
\left(\mathrm{kg} / \mathrm{m}^{3}\right)\end{array}$ & $\begin{array}{l}\mathrm{LCV} \\
(\mathrm{MJ} / \mathrm{kg})\end{array}$ & $\begin{array}{l}\text { Cetane } \\
\text { Number }\end{array}$ & $\begin{array}{l}\text { Kinematic } \\
\text { Viscosity } \\
(\mathrm{cSt}) @ 40^{\circ} \mathrm{C}\end{array}$ & $\begin{array}{l}\text { Flash } \\
\text { Point }\left({ }^{\circ} \mathrm{C}\right)\end{array}$ & $\begin{array}{l}\text { Stoichiometric } \\
\text { Abel }\end{array}$ \\
\hline $\mathrm{D} 100$ & 836 & 43.24 & 52 & 2.45 & 35 & 14.7 \\
$\mathrm{~K} 100$ & 797 & 41.78 & 41.4 & 1.15 & 52 & 14.94 \\
$\mathrm{~K} 5 \mathrm{D}$ & 834.05 & 43.19 & 51.47 & 2.27 & - & 14.712 \\
$\mathrm{~K} 10 \mathrm{D}$ & 832.10 & 43.13 & 50.94 & 2.24 & - & 14.724 \\
$\mathrm{~K} 15 \mathrm{D}$ & 830.15 & 43.05 & 50.41 & 2.22 & - & 14.736 \\
\hline
\end{tabular}

\section{Experimental Set-up}

Experiments were conducted in a four-stroke, single-cylinder, naturally-aspirated, water-cooled, direct-injection diesel engine. The fuel injection system used in the present work was as given by the manufacturer. It had a single-barrel fuel injection pump and inline fuel injector with a three-hole nozzle located near the combustion chamber centre, with an opening pressure of $20.5 \mathrm{MPa}$. The engine piston was a hemispherical bowl-in-piston design. The specifications of the engine are listed in Table 2.

Table 2. Specifications of test engine.

\begin{tabular}{ll}
\hline Model & Kirloskar, TV1 model \\
\hline Engine type & Single-cylinder, four-stroke, water-cooled, DI, diesel \\
Aspiration & Naturally aspirated \\
Bore x Stroke & $87.5 \mathrm{~mm} \times 10 \mathrm{~mm}$ \\
Connecting rod & $234 \mathrm{~mm}$ \\
Displacement & 0.661 litre \\
Compression ratio & $18: 1$ \\
Rated power & $3.7 \mathrm{~kW}$ \\
Rated speed & $1500 \mathrm{rpm}$ \\
Fuel injection system & Single barrel F.I. pump and inline fuel injector \\
Fuel injection timing & $23 \mathrm{deg}$. BTDC (static) \\
Inj. opening pressure & $20.5 \mathrm{MPa}$ \\
Injector holes & $3 \times 0.288 \mathrm{~mm}$ \\
\hline
\end{tabular}

A piezoelectric transducer was installed in the cylinder head in order to measure the pressure inside the cylinder and its signals were fed to a charge amplifier. A highprecision crank angle encoder was used for delivering signals for top dead centre (TDC) and crank angle position. The signals from the charge amplifier and crank angle encoder were fed to a data acquisition system. The engine was coupled with a $400 \mathrm{~kW}$-capacity eddy current dynamometer for loading the engine. Engine load was controlled by varying excitation current to the eddy current dynamometer using a dynamometer controller. The dynamometer was cooled by maintaining water flow at a pressure of 0.1 
MPa. An AVL Digas 444 exhaust gas analyser was used to measure the concentrations of $\mathrm{NO}_{\mathrm{x}}, \mathrm{CO}, \mathrm{CO}_{2}, \mathrm{HC}$ and $\mathrm{O}_{2}$ in the exhaust emissions. It measures $\mathrm{CO}, \mathrm{CO}_{2}$ and $\mathrm{HC}$ emissions with the spectrum analysis principle and $\mathrm{NO}_{\mathrm{x}}$ and $\mathrm{O}_{2}$ with electrochemical sensors. The smoke intensity was measured by using an AVL 437 smoke meter. Engine coolant and calorimeter temperatures were measured using a resistance temperature detector (RTD) and the exhaust gas temperature was measured by ' $\mathrm{K}$ ' type thermocouples during the experiments. Engine temperature was kept constant for all of the tests by varying cooling water flow rate, which was measured by a rotameter. Figure 1 shows a schematic block diagram of the diesel engine test facility used to study engine performance, emissions, and combustion characteristics of kerosene-diesel blends.

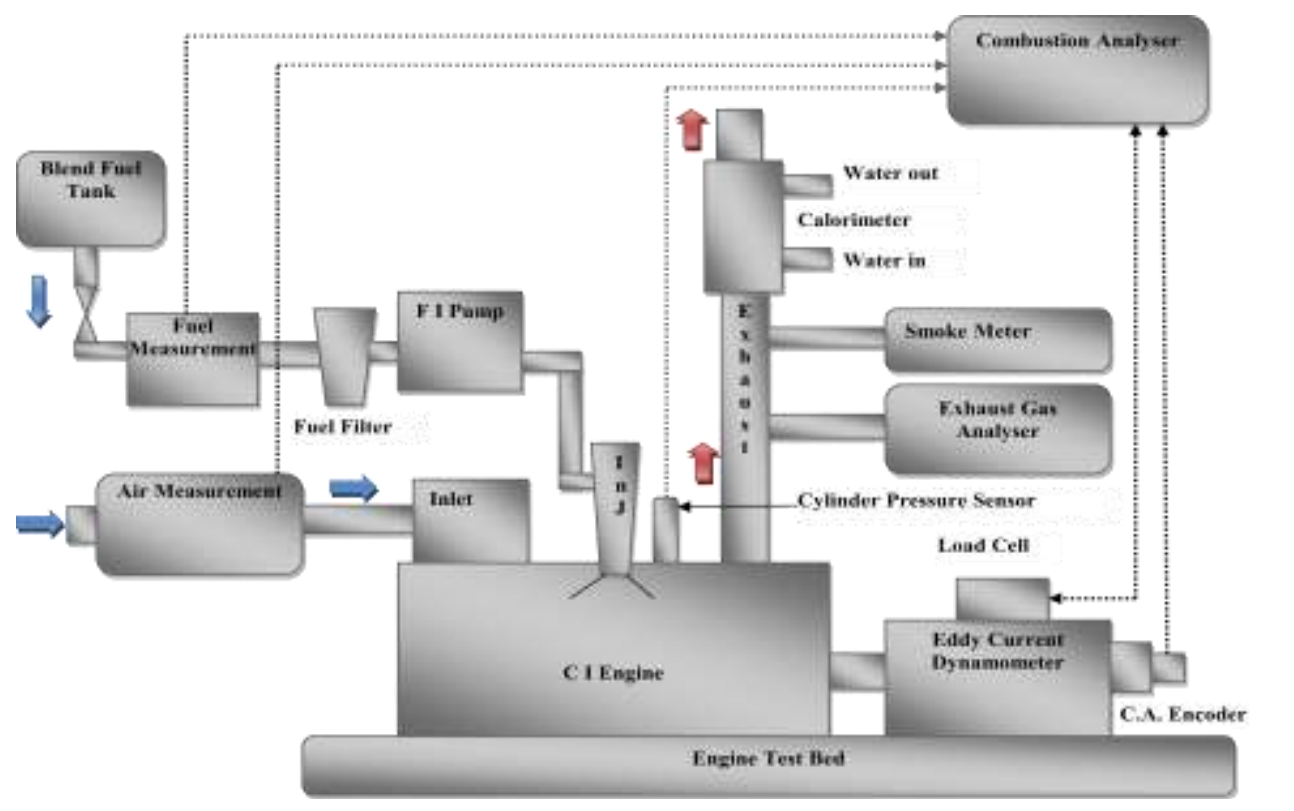

Figure 1. Schematic block diagram of experimental set-up.

\section{Test Procedure}

The engine tests were carried out as per the ISO 8178-D2 five-mode test cycle procedure, as required by the Central Pollution Control Board (CPCB) emission norms, for baseline diesel fuel and three blend fuels at different engine loads. Loads were changed in five levels for $10 \%, 25 \%, 50 \%$, and $75 \%$ of full load and $100 \%$ load. The engine was operated at $1500 \mathrm{rpm}$ for all loads and all the tests. The constant speed of the engine was maintained by adjusting the fuel flow rate manually through a fuelling rack of the fuel injection pump. Before running the engine to a new fuel, the fuel tank and the fuel injection system were cleaned and it was allowed to run for sufficient time to consume any remaining fuel from the previous experiments. The important engine combustion, performance and emission parameters were recorded.

\section{RESULTS AND DISCUSSION}

The experiments were carried out successfully up to a $15 \%$ blending of kerosene (by volume) with diesel fuel. Beyond this limit, the low viscosity and density of the blended fuel can reduce lubricity and create potential wear problems in sensitive fuel injection 
pumps and fuel injector designs. Thus, reduction of lubricity was one of the reasons for keeping less than $15 \%$ kerosene (by volume) in the blends, apart from the effect of reduced viscosity on the spray.

\section{Distillation Tests}

The distillation tests were carried out to determine the boiling range characteristics of a hydrocarbon fuel. The distillation profile is one of the most important and informative parameters that is used for studying complex fluid mixtures. The performance, storage and safety parameters, such as engine starting ability, vapour locking, fuel system icing, fuel auto-ignition, boiling point, fuel injection schedule, vehicle driveability can be studied by using the distillation profile. Based on the ASTM D86 standard procedure, the distillation tests were carried out for baseline diesel and different blends of kerosene with diesel and the results are shown in Figure 2. It can be seen that by adding kerosene to diesel fuel, there was no significant difference observed in the front-end volatility of kerosene-diesel blends. The initial boiling point (IBP) of diesel and blends was $142^{\circ} \mathrm{C}$. However, a significant difference was observed in the tail-end volatility of the kerosenediesel blends compared with diesel fuel, but which remains almost same among all kerosene-diesel blends. Baral and Raine [15] have reported that kerosene improves the cold flow characteristics of diesel fuel by simply diluting the problematic paraffin waxes present in the diesel fuel distillation cut.

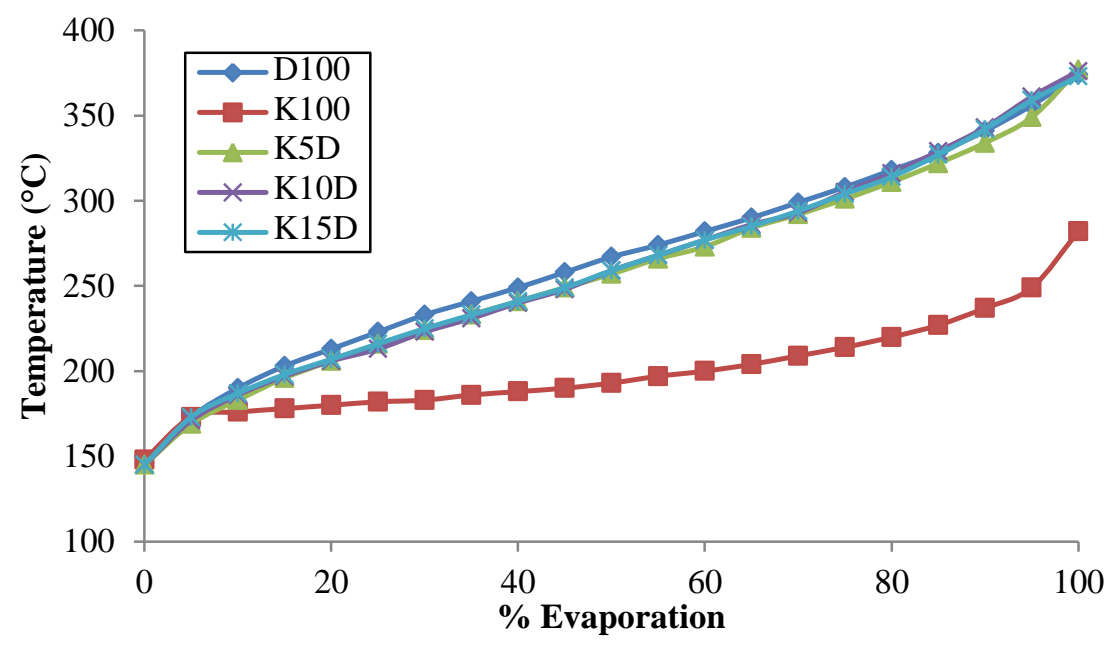

Figure 2. Distillation properties of kerosene-diesel blends.

\section{Combustion Characteristics}

Cylinder pressure against crank angle data recorded in the computer was used to calculate rate of heat release and analyse the combustion characteristics. The net heat release rate is the difference between the heat released by combustion of fuel and the heat absorbed by the cylinder wall. By using the first law of thermodynamics, the net heat release rate, $\mathrm{dQn} / \mathrm{d} \theta$, was calculated with Eq.(1) [10].

$$
\frac{\mathrm{dQn}}{\mathrm{d} \theta}=\frac{\gamma}{\gamma-1} \mathrm{p}\left(\frac{\mathrm{dv}}{\mathrm{d} \theta}\right)+\frac{1}{\gamma-1} \mathrm{~V}\left(\frac{\mathrm{dp}}{\mathrm{d} \theta}\right)
$$

where $\gamma$ is the ratio of specific heats $(\mathrm{Cp} / \mathrm{Cv})$ and $\theta$ is the crank angle. 


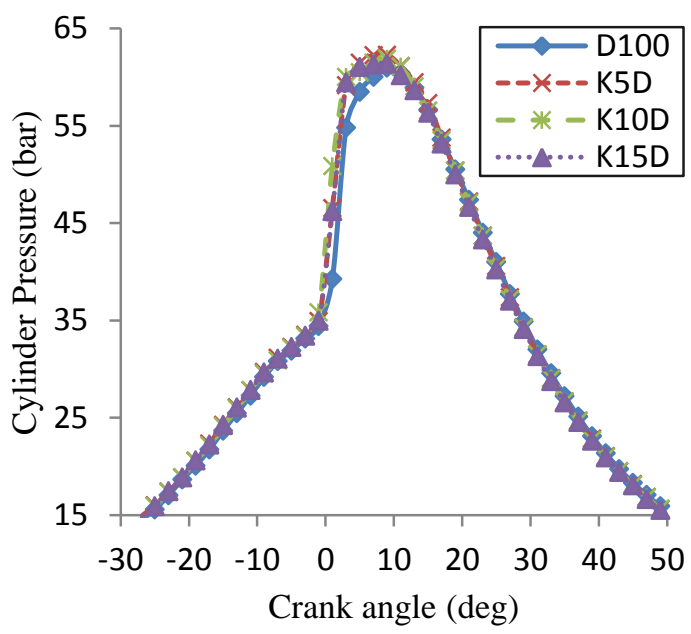

(a)

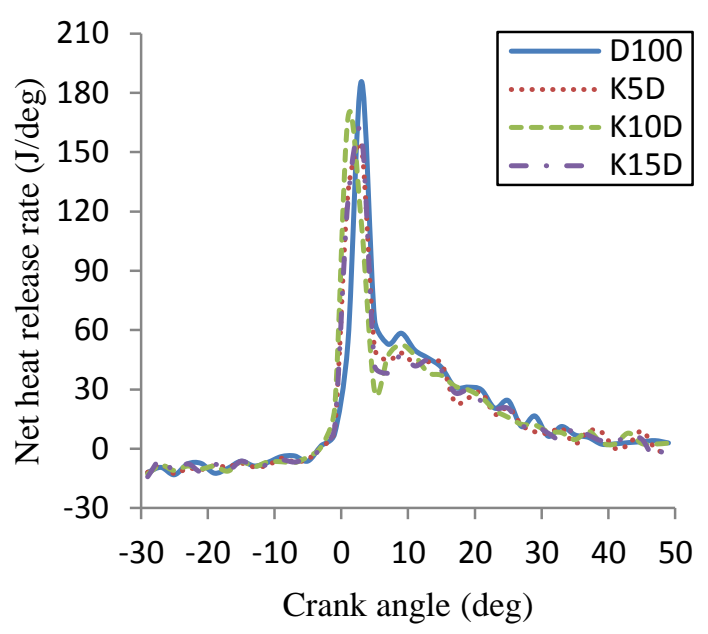

(b)

Figure 3. (a) Cylinder pressure and (b) Net heat release rate vs. crank angle at full load, $1500 \mathrm{rpm}$.

The net heat release rate showed that the ignition delay for the blend fuel was longer than for the diesel fuel, as shown in Figure 3. As the kerosene blend percentage increases the ignition delay also increases. This result was expected due to lower the cetane number of kerosene than diesel, which leads to longer ignition delay. Bergstrand [17] reported that kerosene has a lower cetane number than diesel, thus giving a longer ignition delay, making it viable for lower emissions since the longer ignition delay gives a longer time for the fuel to mix with the air prior to combustion onset.

\section{Performance Characteristics}

The engine brake thermal efficiency, brake specific fuel consumption (BSFC) and exhaust gas temperature are presented against different brake mean effective pressures for K100, K5D, K10D and K15D blends in Figure 4. The BSFC is a measure of the overall efficiency of an engine, which is inversely proportional to the thermal efficiency. Therefore, a lower value of BSFC indicates the higher overall efficiency of an engine [19]. It was observed that the BSFC of the blends was more, while brake thermal efficiency and exhaust gas temperature of the blends were less than the neat diesel. This might be possible due to the reduced calorific value and the smaller fuel delivery amount resulting from the lower density of the blend fuels.

\section{Emission Characteristics}

Smoke formation in a diesel engine is due to heterogeneous combustion and poor mixing of the fuel with air, resulting from an over-rich A/F ratio or partially-evaporated fuel during cold start conditions in a diesel engine. Smoke may be in the form of particles, either solid or liquid, suspended in the exhaust gases. Smoke is a visible aerosol particle and it could be suspended in an atmospheric air medium. Soot is a carbonaceous material impregnated with tar material. Pyrolysis of the fuel results in soot formation under rich conditions. The particulate matter (PM) is a general term which describes both liquid and solid effluents from the combustion. The smoke and 
soot are sub-classifications under PM [20]. The experimental results showed that lower soot emissions were obtained with the kerosene-diesel blends at low load compared with neat diesel, while soot emission was similar to that of diesel fuel at high load; similar results were reported by Bergstrand [17].The variations of smoke, $\mathrm{HC}, \mathrm{NO}_{\mathrm{x}}$ and $\mathrm{CO}$ for different BMEPs at $1500 \mathrm{rpm}$ are shown in Figure 5. Yadav et al. [16] have experimentally demonstrated that the percent opacity value decreased sharply even at a small adulteration level of kerosene with diesel.

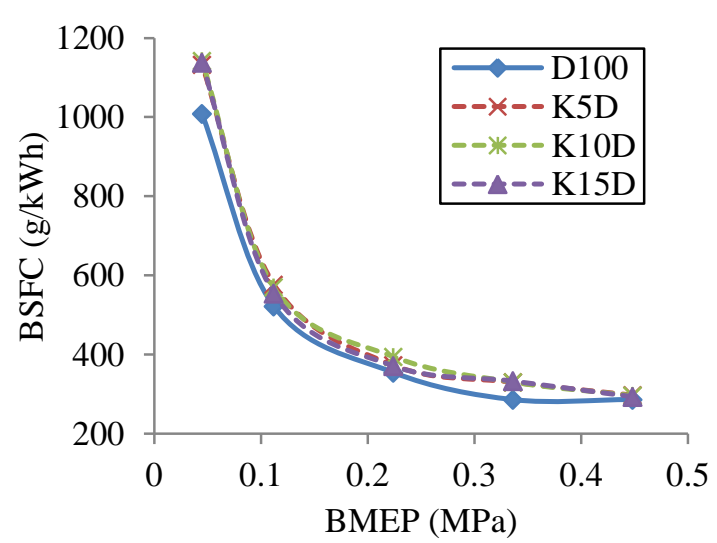

(a)

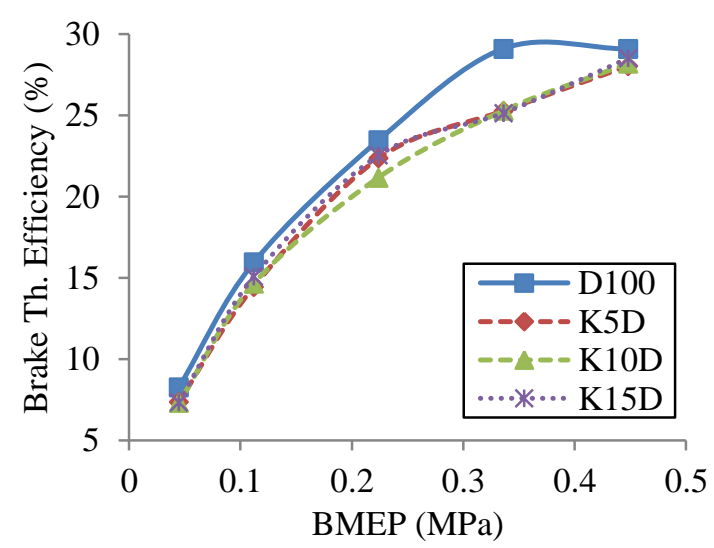

(b)

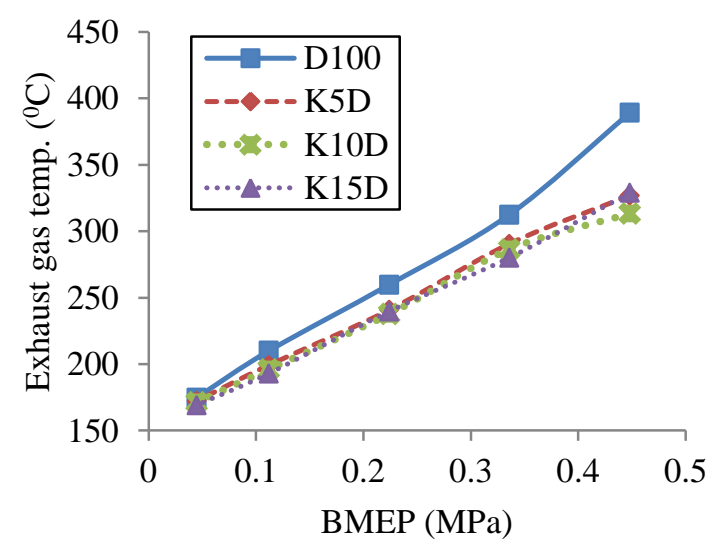

(c)

Figure 4. Variation of (a) BSFC, (b) Brake Thermal Efficiency and (c) Exhaust Gas Temperature with respect to BMEP at $1500 \mathrm{rpm}$

$\mathrm{NO}_{\mathrm{x}}$ refers to a class of compounds called nitrogen oxides, which usually represents a mixture of nitric oxide (NO) and nitrogen dioxide $\left(\mathrm{NO}_{2}\right)$. In diesel engine exhaust, NO is usually the most abundant nitrogen oxide and constitutes more than 70$90 \%$ of total $\mathrm{NO}_{\mathrm{x}}$ [21]. Factors such as the availability of oxygen, combustion temperature, the nitrogen content of the fuel itself, and the reaction time determine $\mathrm{NO}_{\mathrm{x}}$ emissions during the combustion process. The production of $\mathrm{NO}_{\mathrm{x}}$ is proportional to combustion efficiency. Better combustion efficiency gives a higher exhaust temperature, which increases the level of $\mathrm{NO}_{\mathrm{x}}$ production [22]. Most techniques to reduce $\mathrm{NO}_{\mathrm{x}}$ emissions depend on the reduction of peak flame temperature, which can be reduced with retarded injection timing, exhaust gas recirculation (EGR) and split injection. Retarded injection timing reduces peak flame temperatures, and thus $\mathrm{NO}_{\mathrm{x}}$ emissions, at the cost of fuel consumption and particulate emissions [20]. The results 
showed that $\mathrm{NO}_{\mathrm{x}}$ and $\mathrm{CO}$ emissions were reduced with the use of the kerosene-diesel blends with compared with neat diesel fuel, while the unburned hydrocarbon emissions increased with the increase in blend ratio. It was observed that while the blends of kerosene up to $15 \%$ were possible, the most favourable blend was K5D, resulting in low smoke, low $\mathrm{NO}_{\mathrm{x}}$, high brake thermal efficiency and low BSFC compared with K10D and K15D blends. Similar results are reported by Bergstrand [17] and also Mei et al. [21].

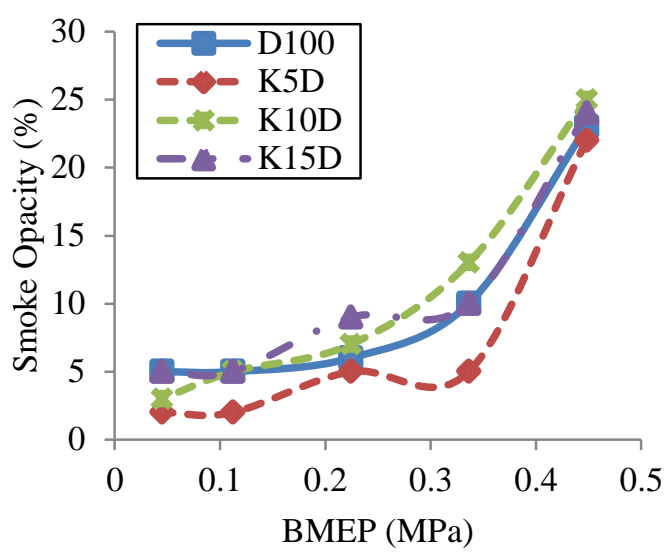

(a)

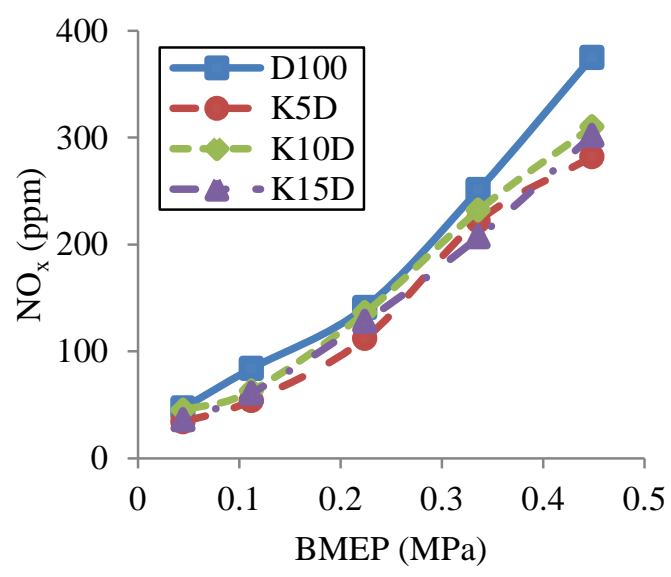

(c)

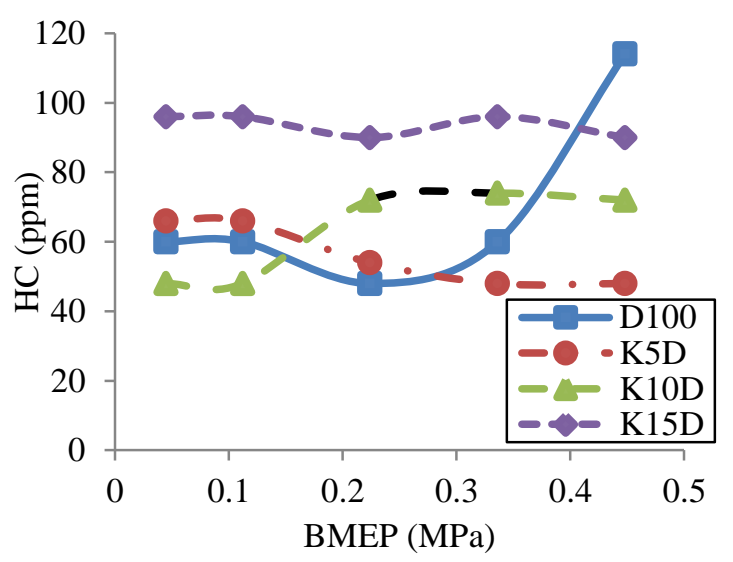

(b)

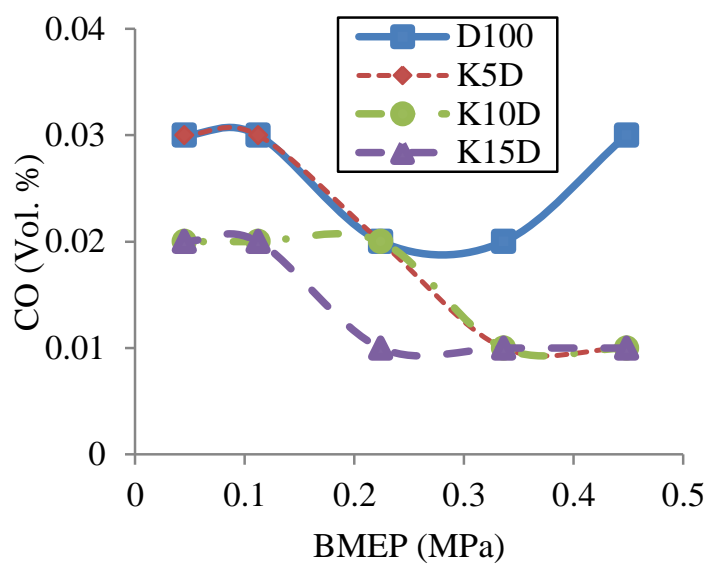

(d)

Figure 5. Variation of (a) smoke, (b) $\mathrm{HC}$, (c) $\mathrm{NO}_{\mathrm{x}}$ and (d) $\mathrm{CO}$ with respect to $\mathrm{BMEP}$ at $1500 \mathrm{rpm}$

\section{CONCLUSIONS}

The experiments were carried out successfully up to $15 \%$ blending of kerosene (by volume) with diesel fuel. The reduction of lubricity was one of the reasons for keeping less than $15 \%$ kerosene (by volume) in the blends, apart from the effect of reduced viscosity on the spray. The experimental results indicate that the smoke, $\mathrm{NO}_{\mathrm{x}}$ and $\mathrm{CO}$ emissions were reduced with the use of the kerosene-diesel blends compared with neat diesel fuel, while the unburned hydrocarbon emissions increase with the increase in blend ratio. It was observed that the K5D blend is most effective combination on the basis of performance and emission characteristics. At an international level, fewer 
efforts by researchers are observed on the use of kerosene-diesel blend fuel in compression ignition engines.

\section{ACKNOWLEDGEMENTS}

This experiment was done in the Internal Combustion Engines Laboratory, M. M. College of Engineering, Pune, India. The authors would like to acknowledge the equipment support extended by VIT, Pune and the fuel test facility provided by Material Testing Laboratory, ARAI, Pune and CHEM-TECH Laboratories Ltd., Pune, India.

\section{REFERENCES}

[1] Kamil M, Rahman MM, Bakar RA. Integrated simulation model for composition and properties of gases in hydrogen fueled engine. International Journal of Automotive and Mechanical Engineering. 2013;8:1242-155.

[2] Kamil M, Rahman MM, Bakar RA. An integrated model for predicting engine friction losses in internal combustion engines. International Journal of Automotive and Mechanical Engineering. 2014;9:1695-708.

[3] Akbari M, Galanis N, Behzadmehr A. Comparative assessment of single and two-phase models for numerical studies of nanofluid turbulent forced convection. International Journal of Heat and Fluid Flow. 2012;37:136-46.

[4] Patil K, Thipse S. Characterisation of the key fuel properties of oxygenated diethyl ether-diesel blends. Applied Mechanics and Materials. 2014; 612,175-80.

[5] Thipse SS. Alternative Fuels. 2nd ed. India: Jaico Publications; 2010.

[6] Kamil M, Rahman MM, Bakar RA. Performance evaluation of external mixture formation strategy in hydrogen fueled engine. Journal of Mechanical Engineering and Sciences. 2011;1:87-98.

[7] Kalyani Radha K, Naga Sarada S, Rajagopal K, Nagesh EL. Performance and emission characteristics of a CI engine operated on vegetable oils as alternative fuels. International Journal of Automotive and Mechanical Engineering. 2011;4:414-27.

[8] Mat Yasin MH, Mamat R, Sharma KV, Yusop AF. Influence of palm methyl ester (PME) as an alternative fuel in multicylinder diesel engine. Journal of Mechanical Engineering and Sciences. 2012;3:331-9.

[9] Gharehghani A, Hosseini R, Yusaf T. Investigation of the effect of additives to natural gas on heavy-duty si engine combustion characteristics. Journal of Mechanical Engineering and Sciences. 2013;5:677-87.

[10] Ghobadian B, Najafi G, Nayebi M. A semi-empirical model to predict diesel engine combustion parameters. Journal of Mechanical Engineering and Sciences. 2013;4:373-82.

[11] Yusop AF, Mamat R, Mat Yasin MH, Ali OM. Effects of particulate matter emissions of diesel engine using diesel-methanol blends. Journal of Mechanical Engineering and Sciences. 2014;6:959-67.

[12] Mohanamurugan S, S S. Emission and combustion characteristics of different fuels in a HCCI engine. International Journal of Automotive and Mechanical Engineering. 2011;3:279-92.

[13] Mohanamurugan S, Sendilvelan S. Emission and combustion characteristics of different fuel In A HCCI engine. International Journal of Automotive and Mechanical Engineering. 2011;3:279-92. 
[14] Aziz Hairuddin A, Wandel AP, Yusaf T. Effect of different heat transfer models on a diesel homogeneous charge compression ignition engine. International Journal of Automotive and Mechanical Engineering. 2013;8:1292-304.

[15] Baral B, Raine R. Performance and emissions of a spark ignition engine running on gasoline adulterated with kerosene. SAE Technical Paper No. 2009-28-0014; 2009.

[16] Yadav SR, Murthy V, Mishra D, Baral B. Estimation of petrol and diesel adulteration with kerosene and assessment of usefulness of selected automobile fuel quality test parameters. International Journal of Environmental Science \& Technology. 2005;1:253-5.

[17] Bergstrand P. Effects on combustion by using kerosene or MK1 diesel. SAE Technical Paper No. 2007-01-0002; 2007.

[18] Pathak S, Aigal A, Sharma M, Narayan L, Saxena M. Reduction of exhaust emissions in a kerosene operated genset for electrical energy applications. SAE Technical Paper No. 2005-26-026; 2005.

[19] Azad AK, Ameer Uddin SM, MM A. A comprehensive study of DI diesel engine performance with vegetable oil: an alternative bio-fuel source of energy. International Journal of Automotive and Mechanical Engineering. 2012;5:57686.

[20] Liaquat A, Masjuki H, Kalam M, Varman M, Hazrat M, Shahabuddin M, et al. Application of blend fuels in a diesel engine. Energy Procedia. 2012;14:112433.

[21] Mei D, Hielscher K, Baar R. Study on Combustion process and emissions of a single-cylinder diesel engine fueled with DMC/diesel blend. Journal of Energy Engineering. 2013;140.

[22] Yusaf T, Hamawand I, Baker P, G N. The effect of methanol-diesel blended ratio on $\mathrm{CI}$ engine performance. International Journal of Automotive and Mechanical Engineering. 2013;8:1385-95. 